\title{
Hajdú-Bihar megye társadalmi helyzetének bemutatása a számok tükrében
}

\section{Introducing the social situation of Hajdú-Bihar County in numbers}

\author{
VIDA V. - SzÜCS I.
}

\begin{tabular}{|c|c|c|c|}
\hline $\begin{array}{l}\text { Debreceni } \quad \text { Egyetem } \\
\text { vida.viktoria@econ.unideb.hu }\end{array}$ & Gazdaságtudományi & Kar, & Gazdálkodástudományi \\
\hline Debreceni & Gazdaságtudományi & Kar, & Gazdálkodástudományi \\
\hline
\end{tabular}

Absztrakt

Az általunk készitett tanulmány célja, hogy áttekintést nyújtson Hajdú-Bihar megye társadalmi helyzetének alakulásáról. Hajdú-Bihar megye, az Észak-alföldi régió gazdasági, oktatási, tudományos és kulturális szerepkörrel bíró központja. Adottságai kedvezöek a szerepkör betöltéséhez, gazdasági, oktatási, kereskedelmi, kulturális, egészségügyi kapcsolatai az országhatáron túl is jelentösek. Hajdú-Bihar megyével kapcsolatban fontosnak tartjuk még megemliteni a logisztikai szerepének kiaknázását, valamint regionális tudásbázis szerepkörét bemutatni. Hajdú-Bihar megye központja Debrecen város, a népességszámát tekintve Magyarország második, az Alföld legnagyobb városa. Debrecen már évtizedek óta Hajdú-Bihar megye kiemelkedö települése, a város társadalmi-gazdasági hatása az egész régióra kiterjed, hiszen a város regionális központként is funkcionál. A fentebb emlitett hatások közül jelen tanulmányban Hajdú-Bihar megye társadalmi hatásaira fókuszálunk, és ennek elemzéséhez, alátámasztásához a helyi és az országos statisztikai adatokat alapul véve készitettünk számításokat. A társadalmi hatásokat elsösorban demográfiai szempontból vizsgáltuk meg (népesség száma, nem, kor és iskolai végzettség szerinti összetétele, képzettsége, foglalkoztatottsága, jövedelmi viszonyok) a korábbi évekkel és országos adatokkal összehasonlítva.

Kulcsszavak: Hajdú-Bihar megye, társadalom, lakosság, foglalkoztatottság, jövedelmi viszony

Abstract

The aim of our study is to provide an overview of the social situation in Hajdú-Bihar County. Hajdú-Bihar County, the economic, educational, scientific and cultural center of the Northern Great Plain region. Its conditions are favorable for fulfilling its role, and it's economic, educational, commercial, and cultural and health relations are significant beyond the national borders. In connection with Hajdu-Bihar County, it is important to mention the utilization of its logistics role and the role of the regional knowledge base. Debrecen city is the center of HajduBihar County, this is the second largest city in Hungary in terms of population. For decades Debrecen has been an outstanding role of Hajdu-Bihar County, and the city has a socio-economic impact on the whole region as a regional center. Among the above-mentioned impacts, this study focuses on the social impacts of Hajdu-Bihar County and the calculations based on local and national statistics to support and analyze this impact. The social impacts were examined primarily from a demographic point of view (population, gender, age and composition by educational level, qualifications, employment, income conditions) compared to previous years and national data.

Keywords: Hajdú-Bihar County, society, population, employment, income situation,

JEL code: R23 Urban, rural, regional, real estate and transportation economics: regional migration, regional labour markets, population, neighbourhood characteristics 


\section{Bevezetés, témafelvetés}

Hajdú-Bihar megye, az Észak-alföldi régió gazdasági, oktatási, tudományos és kulturális szerepkörrel bíró központja, egyike az ország tényleges, teljes körü regionális központjainak. Adottságai kedvezőek a nagytérségi szerepkör betöltéséhez, gazdasági, oktatási, kereskedelmi, kulturális, egészségügyi kapcsolatai az országhatáron túl is jelentősek. A város évszázadok óta a különböző adottságú és jellegü vidékek közötti munkamegosztás közvetítője, szervezője és irányítója, ezért kiemelten fontosnak tartjuk, hogy közelebbről is megvizsgáljuk a megye jelentőségét elsősorban társadalmi szempontból, ahogyan a címben is szerepel. A szomszédos országok gazdasági életében is fontos szerepet játszó városokkal (Nagyvárad, Székelyudvarhely, Szatmárnémeti, Ungvár, Munkács) kapcsolatai jelentősek, így a megye hatása akár határokon túlra is átível.

Hajdú-Bihar megye megyeszékhelye Debrecen város, amellyel kapcsolatban első helyen kell említeni a gazdag történelmi hagyományokból táplálkozó, kimagasló oktatási szerepkörét, amely kisebb mértékben már a középiskolák szintjén is jelentkezik, de igazán a felsőoktatásban teljesedik ki. A Debreceni Egyetem és más felsőoktatási intézmények országos, sőt számos esetben (pl. orvosképzés esetében) nemzetközi vonzáskörzettel is rendelkeznek. A kutatás területén is erősek a megye pozíciói, a Debreceni Egyetem mellett több jelentős kutatóintézet is müködik. A város már régóta a hazai kulturális élet egyik meghatározó központja, amely szerepköre a közelmúltban végrehajtott beruházásoknak (Kölcsey Központ, MODEM, Főnix Csarnok) és a számos kulturális rendezvénynek (pl. Campus fesztivál, gasztronómiai rendezvények) köszönhetően még tovább bővült (Internet 1.).

A megyeszékhely egyben egyházi központ is, a reformáció hazai fellegvára. A Debreceni Református Kollégium müködésének kezdetét jelző 1538-as esztendőtől számíthatjuk a reformátori vezetés meglétét, de nehéz rögzíteni egy olyan időpontot, amely előtt még nem beszélhetünk a reformáció jelenlétéről egy városban, amely után azonban már kizárólag csak református városról beszélhetnénk (Bajkó et. al., 1988). A 16. században a reformáció térhódításával a városban megszünt a római katolikus egyházi élet, ám két és fél évszázad kényszerü távollét után visszatért a „kálvinista Rómába” a római katolikus egyház. Ferenc József debreceni látogatása során szóvá tette: „mily nagy hiba, hogy Debrecenben görögkatolikus egyház még szervezve nincsen", ezzel vette kezdetét a görögkatolikus egyházszervezés Debrecenben (Internet 2.). Az építészeti stílusok, különösen az egyházi épületek, templomok, imahelyek külső megjelenése mindamellett ad egyfajta morfológiai képet egy városnak, településnek (Bartha, 1992).

A kiemelkedő oktatási és egyházi szerep mellett itt működik számos intézmény, vállalat és szolgáltató cég központja növeli a város, a megye egyben regionális szerepkörét. Debrecen, mint megyeszékhely megyei adminisztrációs, közigazgatási centrum, egyes ilyen jellegü funkciói ugyanakkor kiterjednek Jász-Nagykun-Szolnok és Békés megyékben egyes területeire is. Hajdú-Bihar megye egészségügyi vonzáskörzete is túlmutat a megyehatáron (Internet 1.). Debreceni lakosként mindig is szívügyünknek tekintettük, és figyelemmel kísértük a megye, és a város sorsát, hiszen a kettő szorosan összefonódik, bár a jelen tanulmányban elsősorban Hajdú-Bihar megye áll a kutatás középpontjában. Ez a fajta lokálpatriotizmus és a fentebb említett indokok, eredmények és hatások teszik indokolttá, hogy ebben a tanulmányban Hajdú-Bihar megye társadalmi hatásait mélyebben megvizsgáljuk, és ennek elemzéséhez, alátámasztásához a helyi és az országos statisztikai adatokat alapul véve készítettünk számításokat. Ezeket az adatokat lehetőség szerint összehasonlítottuk az országos adatokkal, vagy más hasonló megyék adataival, hogy árnyaltabb képet mutathassunk a megye helyzetéről.

\section{Anyag és módszerek}

Ahogyan már korábban említésre került, a társadalmi hatásokat elsősorban demográfiai szempontból vizsgáltuk meg, elöször is bemutatva a népesség számát, nem, és kor szerinti összetételét, majd a természetes szaporodás illetve fogyás folyamatait vizsgáltuk meg. A természetes szaporodást, illetve fogyást az élveszületések és a halálozások különbözeteként határoztuk meg, és korrigáltuk a belső és nemzetközi vándorlási folyamatokkal. Élveszületés (az ENSZ ajánlásának megfelelően): a magzat világrajövetele, amennyiben az újszülött az életnek valamilyen jelét adja, tekintet nélkül arra, hogy mennyi ideig volt az anya méhében és mennyi ideig élt. Halálozás (az ENSZ ajánlásának megfelelően): az élet minden jelének végleges elmúlása az élveszületés megtörténte után bármikor (az életmüködésnek a születés utáni megszünése, a feléledés képessége nélkül). 
Ezt követően a megyére jellemző egyéb társadalmi adatok kerültek elemzésre, úgymint a munkanélküliségi ráta, foglalkoztatottság, a teljes munkaidőben alkalmazásban állók havi nettó és bruttó átlagkeresete, melyeket országos és más megyék adataival összehasonlításban vizsgáltunk meg.

A helyi és az országos statisztikai adatokat alapul véve készítettünk el a számításainkat, az adatok forrása elsősorban a Központi Statisztikai Hivatal (KSH), a Magyar Államkincstár (MÁK), a Nemzeti Adó- és Vámhivatal (NAV), és az Országos Területfejlesztési és Területrendezési Információs rendszerből származó (TEIR) adatgyüjtések voltak. A közölt adatok területi csoportosítása az adott év január 1-jei közigazgatási beosztása szerint történt. A százalék-és viszonyszámok számítása kerekítés nélküli adatokból történt, hosszú idősoros adatok alapján. A népességre vetített mutatókat lakónépességi adatok alapján számítottuk.

\section{Eredmények}

Jelenleg Hajdú-Bihar megye a második legnépesebb megyéje az Észak-Alföldi régiónak, népességi indexét és népsürüségét tekintve is második az Észak-Alföldi régiót adó három megye közül. A megye lakónépessége a legfrissebb adatok szerint 2019. január 1-jén 528 ezer fö volt, 0,5\%-kal kevesebb, mint egy évvel korábban. Magyarország lakónépességéhez viszonyítva, az ország lakosságának 5,4\%-a él itt. Az elmúlt közel 150 évben a megye lakónak száma jelentősen megváltozott, az 1870-es évekhez képest majdnem megduplázódott. A népsürüség már árnyaltabb képet mutat, de a 2001-es év végére az is majdnem kétszeresére emelkedett. A rendszerváltás követően, ha csak az elmúlt harminc év távlatából vizsgáljuk meg a megye lakosainak számát, akkor megállapíthatjuk, hogy a lakók száma csak kis mértékben változott. A legnagyobb lélekszáma a megyének 2001-ben (közel 553 ezer fö) és 1980-ban (551 ezer fö) volt, azóta folyamatos csökkenés tapasztalható, hasonló tendenciát mutat a népsürüség is. A megyeszékhely lakosainak száma az elmúlt 30 évben alig változtak, hiszen 1990-ben 212 ezer fö volt, 2001-ben 211 ezer fö volt, és az utolsó KSH népszámlálási adatokat alapul véve 2011-ben 211320 fö volt.

1. táblázat: Hajdú-Bihar megye népesség számának alakulása és népsürüsége (1870-2018) Table 1: Population and population density of Hajdú-Bihar County (1870-2018)

\begin{tabular}{|c|c|c|}
\hline $\mathbf{E} \mathbf{v}$ & Népesség (fö) & Népsürüség $\left(\mathbf{f o ̈} / \mathbf{k m}^{2}\right)$ \\
\hline $\mathbf{1 8 7 0}$ & 281350 & 45,3 \\
\hline $\mathbf{1 8 8 0}$ & 289311 & 46,6 \\
\hline $\mathbf{1 8 9 0}$ & 322286 & 51,9 \\
\hline $\mathbf{1 9 0 0}$ & 364908 & 58,8 \\
\hline $\mathbf{1 9 1 0}$ & 406290 & 65,4 \\
\hline $\mathbf{1 9 2 0}$ & 426465 & 68,7 \\
\hline $\mathbf{1 9 3 0}$ & 467257 & 75,2 \\
\hline $\mathbf{1 9 4 1}$ & 496009 & 79,9 \\
\hline $\mathbf{1 9 4 9}$ & 498271 & 80,2 \\
\hline $\mathbf{1 9 6 0}$ & 522787 & 84,2 \\
\hline $\mathbf{1 9 7 0}$ & 531508 & 85,6 \\
\hline $\mathbf{1 9 8 0}$ & 551448 & 88,8 \\
\hline $\mathbf{1 9 9 0}$ & 548728 & 88,4 \\
\hline $\mathbf{2 0 0 1}$ & 552998 & 89,0 \\
\hline $\mathbf{2 0 1 1}$ & 546721 & 88,0 \\
\hline $\mathbf{2 0 1 8}$ & 527989 & 85,0 \\
\hline
\end{tabular}

Forrás: saját szerkesztés a KSH adott évi népszámlálási kötetei alapján, 2019

A népességszám változását befolyásoló tényezők: az élveszületések és a halálozások egyenlegeként kialakuló természetes szaporodás vagy fogyás, és a nemzetközi és belföldi migrációs folyamatok egyenlege. A tényleges szaporodást befolyásoló két tényező közül a természetes népesedési 
folyamatokat tekintve természetes fogyás, míg a vándorlási különbözet tekintetében évenként változó eredmény tapasztalható (2. táblázat).

A 2. táblázat adatait mélyebben elemezve megállapíthatjuk, hogy 2001 óta pozitív változás a népesség alakulásában nem volt, fokozatosan csökken Hajdú-Bihar megye lakosainak a száma. Az viszont nem egyértelmü, hogy az egyes években a lakosság természetes fogyása, vagy a belföldi migráció járul inkább hozzá a lélekszám csökkenéséhez. Vannak évek, amikor a természetes fogyás jelentősen meghaladja a belföldi elvándorlás számait, míg 2011-es évtől napjainkig az a jellemzőbb, hogy a belföldi migráció olyan mértékü, hogy a természetes fogyás számadatait is meghaladja (de 2008-ban és 2009ben is hasonló volt a helyzet). A nemzetközi vándorlási különbözet 2009-ben és 2011-ben volt a legjelentősebb (ezek az adatok valószínüleg a globális gazdasági válság hatásaival és utóhatásaival magyarázhatóak), és a különbség 2016-ban volt a legalacsonyabb.

2. táblázat: Hajdú-Bihar megye népmozgalmi eseményei (2001-2018)

Table 2: Population Change of Hajdú-Bihar County (2001-2018)

\begin{tabular}{|c|c|c|c|c|c|c|c|c|c|}
\hline $\begin{array}{c}\text { Hajdú-Bihar } \\
\text { megye }\end{array}$ & $\mathbf{2 0 0 1}$ & $\mathbf{2 0 0 2}$ & $\mathbf{2 0 0 3}$ & $\mathbf{2 0 0 4}$ & $\mathbf{2 0 0 5}$ & $\mathbf{2 0 0 6}$ & $\mathbf{2 0 0 7}$ & $\mathbf{2 0 0 8}$ & $\mathbf{2 0 0 9}$ \\
\hline $\begin{array}{c}\text { Természetes } \\
\text { szaporodás/fogyás } \\
\text { (fö) }\end{array}$ & -750 & -871 & -1088 & -996 & -1172 & -1055 & -1140 & -1102 & -1127 \\
\hline $\begin{array}{c}\text { Belföldi } \\
\text { vándorlási } \\
\text { különbözet (fö) }\end{array}$ & -322 & -239 & -1032 & -514 & -1039 & -1323 & -1049 & -1634 & -1304 \\
\hline $\begin{array}{c}\text { Nemzetközi } \\
\text { vándorlási } \\
\text { különbözet (fó) }\end{array}$ & 286 & 469 & 548 & 617 & 196 & 662 & 350 & 1126 & 1537 \\
\hline $\begin{array}{c}\text { Tényleges } \\
\text { szaporodás, } \\
\text { fogyás (fö) }\end{array}$ & -786 & -641 & -1572 & -893 & -2015 & -1716 & -1839 & -1610 & -894 \\
\hline $\begin{array}{c}\text { Hajdú-Bihar } \\
\text { megye }\end{array}$ & $\mathbf{2 0 1 0}$ & $\mathbf{2 0 1 1}$ & $\mathbf{2 0 1 2}$ & $\mathbf{2 0 1 3}$ & $\mathbf{2 0 1 4}$ & $\mathbf{2 0 1 5}$ & $\mathbf{2 0 1 6}$ & $\mathbf{2 0 1 7}$ & $\mathbf{2 0 1 8}$ \\
\hline $\begin{array}{c}\text { Természetes } \\
\text { szaporodás, } \\
\text { illetve fogyás (fö) }\end{array}$ & -1441 & -1366 & -1379 & -1224 & -925 & -1132 & -672 & -1074 & -1408 \\
\hline $\begin{array}{c}\text { Belföldi } \\
\text { vándorlási } \\
\text { különbözet (fö) }\end{array}$ & -1260 & -1624 & -1994 & -1270 & -2027 & -1905 & -2098 & -2089 & -2377 \\
\hline $\begin{array}{c}\text { Nemzetközi } \\
\text { vándorlási } \\
\text { különbözet (fó) }\end{array}$ & 1077 & 1353 & 1273 & 649 & 713 & 743 & 195 & 1228 & 1310 \\
\hline $\begin{array}{c}\text { Tényleges } \\
\text { szaporodás, } \\
\text { fogyás (fó) }\end{array}$ & -1624 & -1637 & -2100 & -1845 & -2239 & -2294 & -2575 & -1935 & -2475 \\
\hline
\end{tabular}

Forrás: saját készités a KSH adatai alapján, 2019

Természetes fogyás jellemzi az ország minden megyéjét, viszont a $K S H, 2018$-as adatokat alapul véve a többi megyével összehasonlításban megállapítható, hogy a hetedik helyet foglaljuk el a népességszám csökkenés tekintetében, ezzel így erős középmezőnyben helyezkedik el Hajdú-Bihar megye.

A TEIR adatbázis alapján pedig (1. ábra) megállapítható, hogy a természetes fogyás (azaz az élvszületések és a halálozások különbsége) nemcsak megyei probléma, hanem országosan a legnagyobb a különbség. A regionális (kék vonal), és a megyei (zöld vonal) adatok teljesen összhangban mozognak az országos tendenciával (narancssárga vonal), csak kisebb mértékben változnak. A Debrecenre vonatkozó értékek (sárga oszlop), és a járási adatok (lila vonal) egymással összhangban, viszont az országos, regionális, és megyei tendenciáktól eltérően változnak. A Debrecenre vonatkozó 2008 -as adat megegyezik az Észak-Alföldi régió adatával, és meghaladta a megyei adatokat. Majd 2009-re jelentős 
csökkenés következett be az ezer lakosra jutó természetes fogyásban, amely azóta már emelkedett, de azóta sem érte el a régiós szintet, és a megyeit is csak 2016-ban közelítette meg. A Debreceni járás, Debrecen és Hajdúsámson együttesen, kizárólag ez a két város tartozik hozzá, községek közül egyetlen sem. A Debreceni járás adatai azért kedvezőbbek, mert Hajdúsámson pozitív természetes szaporodása (mint a Debreceni járásba tartozó település) kedvezően hat a mutató alakulására, ezért tartjuk indokoltnak az 1. ábrán a járási adatokat is bemutatni. Hasonló a helyzet a Központi Statisztikai Hivatal által lehatárolt Debreceni nagyvárosi település-együttes többi településén, ahol a természetes népesedési folyamatok vonatkozásában kiegyenlítettek a viszonyok (minimális fogyás tapasztalható), ugyanakkor jelentős a vándorlási pozitívum.

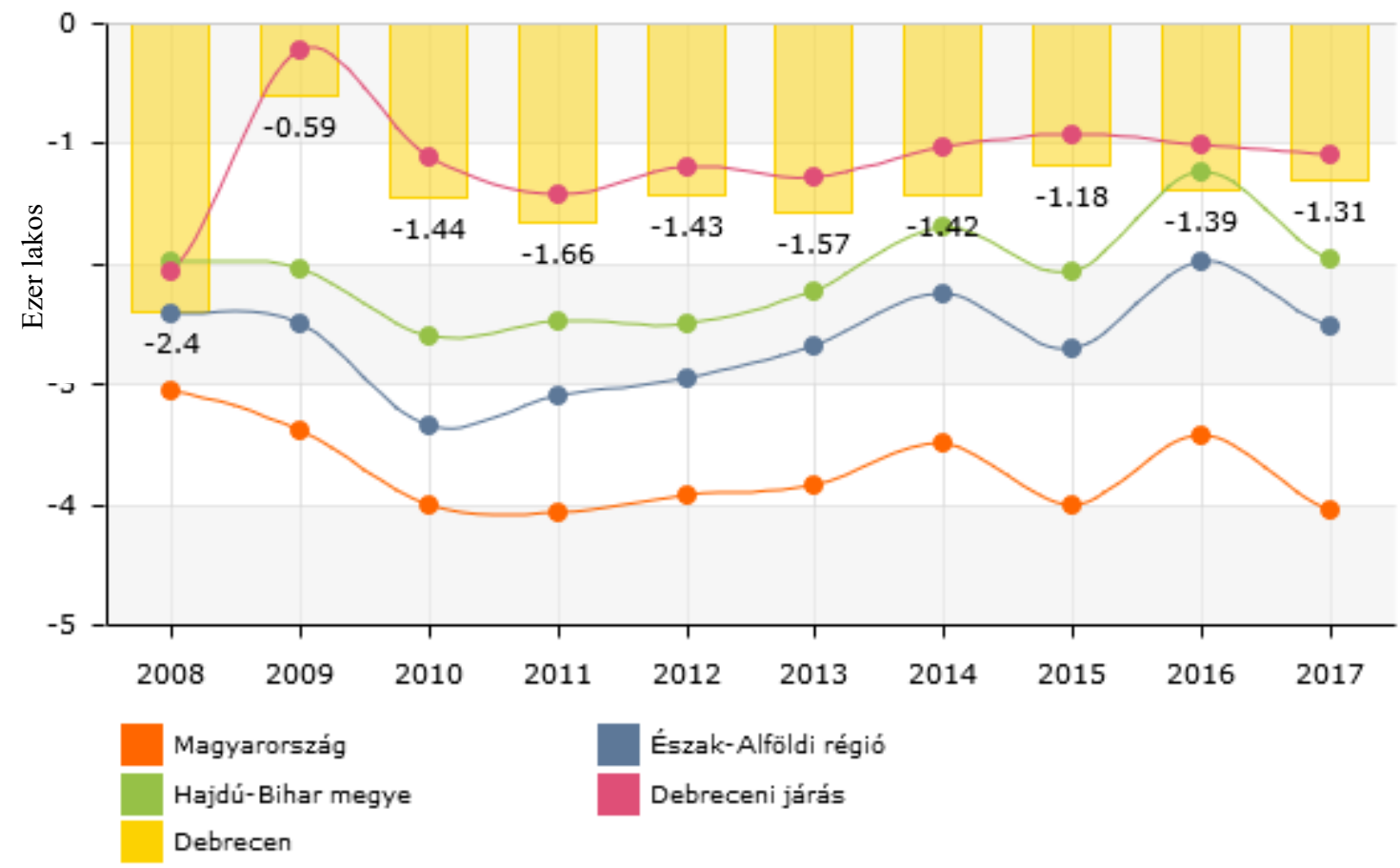

1. ábra: Az élve születések és a halálozások különbözete ezer lakosra vetitve (2008-2017)

Figure 1: The difference between live births and deaths per thousand inhabitants (2008-2017)

Forrás: TEIR adatai alapján, 2019

A megyék közötti elvándorlást szemlélteti a 2. ábra, melyen a megyék közötti vándorlási kapcsolatok kerültek megjelenítésre, az egyes megyék közötti oda- és elvándorlások különbözetei alapján.

A 2. ábrán a pozitív vándorlási egyenlegü megyékhez az a három megye lett hozzárendelve, ahonnan a legnagyobb vándorlási nyereségük származott, míg a negatív vándorlási egyenlegü megyék mindegyikéhez három olyan megye tartozik, amelyekkel a népességcsere-folyamataik leginkább veszteségesek voltak. A diagramon a nyíl iránya jelzi, hogy hová vándorolnak többen, a nyíl színe pedig azt jelzi, hogy honnan vándorolnak el. A nyilak méretei a migrációs egyenlegek nagyságát tükrözik.

A 2. ábrán az is jól látható, hogy Hajdú-Bihar megyéből leginkább Budapest, Pest megye, Győr-MosonSopron megye és Komárom-Esztergom megye irányába történik. Összességében elmondható, hogy a régiók közül Észak-Alföld népességmegtartó ereje volt a leggyengébb, a régióban 8750 fövel csökkent a népességszám a belföldi migrációból eredően ( $K S H, 2017)$. 


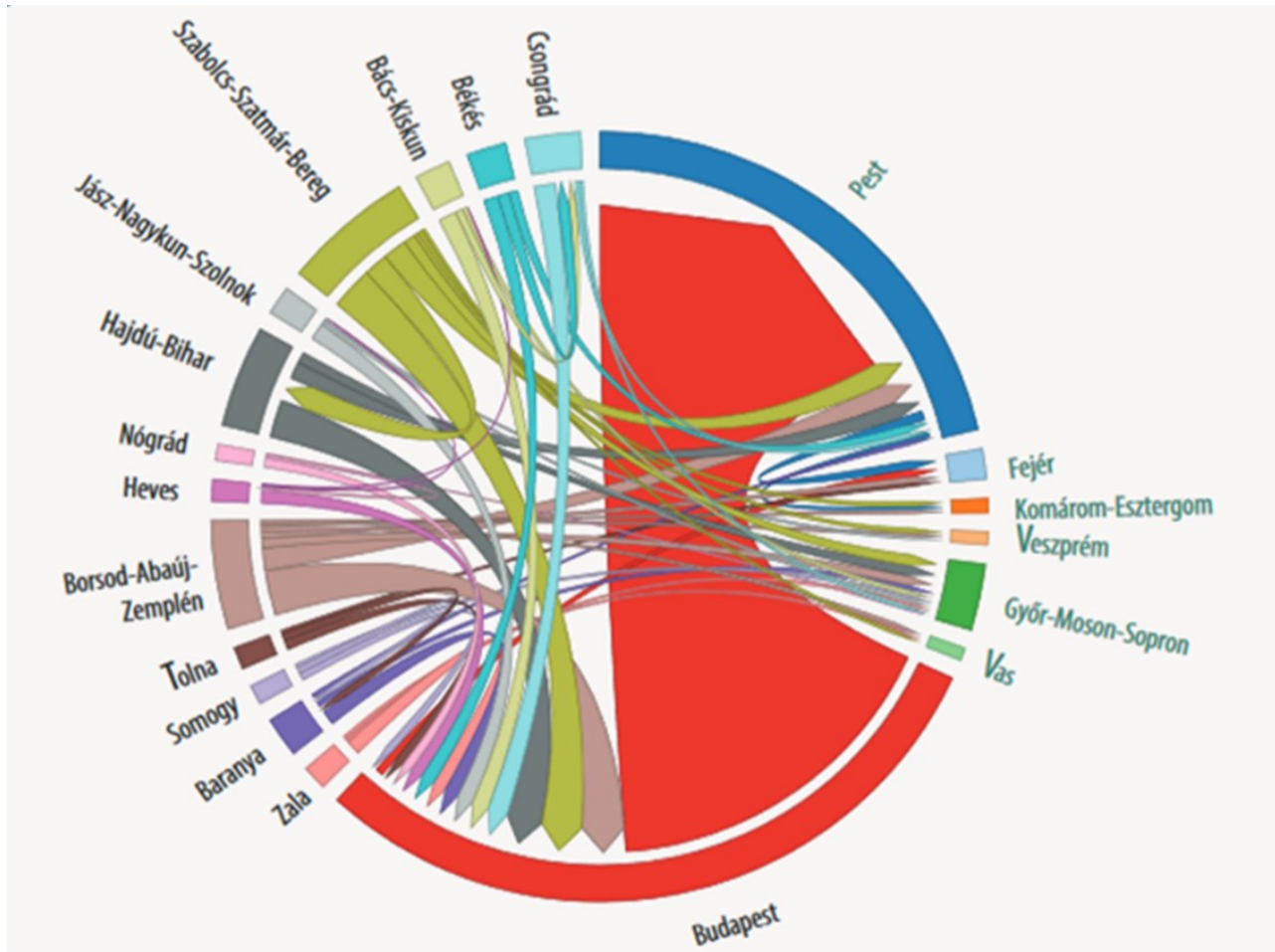

2. ábra: A megyék közötti belföldi vándorlási különbözet

Forrás: KSH, 2017 Figure 2: Domestic migration difference between counties

A belföldi vándorlás vizsgálatához elengedhetetlen az egyes területek társadalmi és gazdasági folyamatait is figyelembe venni. A KSH, 2017 adatai alapján az egy före jutó GDP-t vizsgálva megállapítható, hogy azokban a megyékben, ahol pozitív a vándorlási mérleg, ott az egy főre jutó GDPnek az emelkedése meghaladta az országos átlagot, míg ahol negatív a vándorlási mérleg, az egy forre jutó GDP összege nem érte el az ország átlagos GDP szintjét. Egy adott megye munkaerő piaci helyzete is hatással van a vándorlási folyamatokra. Az is megfigyelhető, hogy a vándorlási nyereséggel rendelkező régiók munkanélküliségi rátája az országos átlag alatt maradt, míg a negatív vándorlási mérleggel rendelkező régiók esetében az országos átlagnál magasabb volt a munkanélküliségi ráta, de ezt a későbbiekben részletesebben kifejtjük.

A népesség lélekszámának elemzése után érdemes megvizsgálni a korcsoportok szerinti megoszlását (3. ábra), amelyen igen jelentős változások figyelhetőek meg. Az ábrán a lakónépességet 0-14 éves (gyermek), 15-64 éves, és 65 év feletti (nyugdíjas) korosztályra osztottuk fel, így ki lehet számolni az úgynevezett öregedési rátát is. 


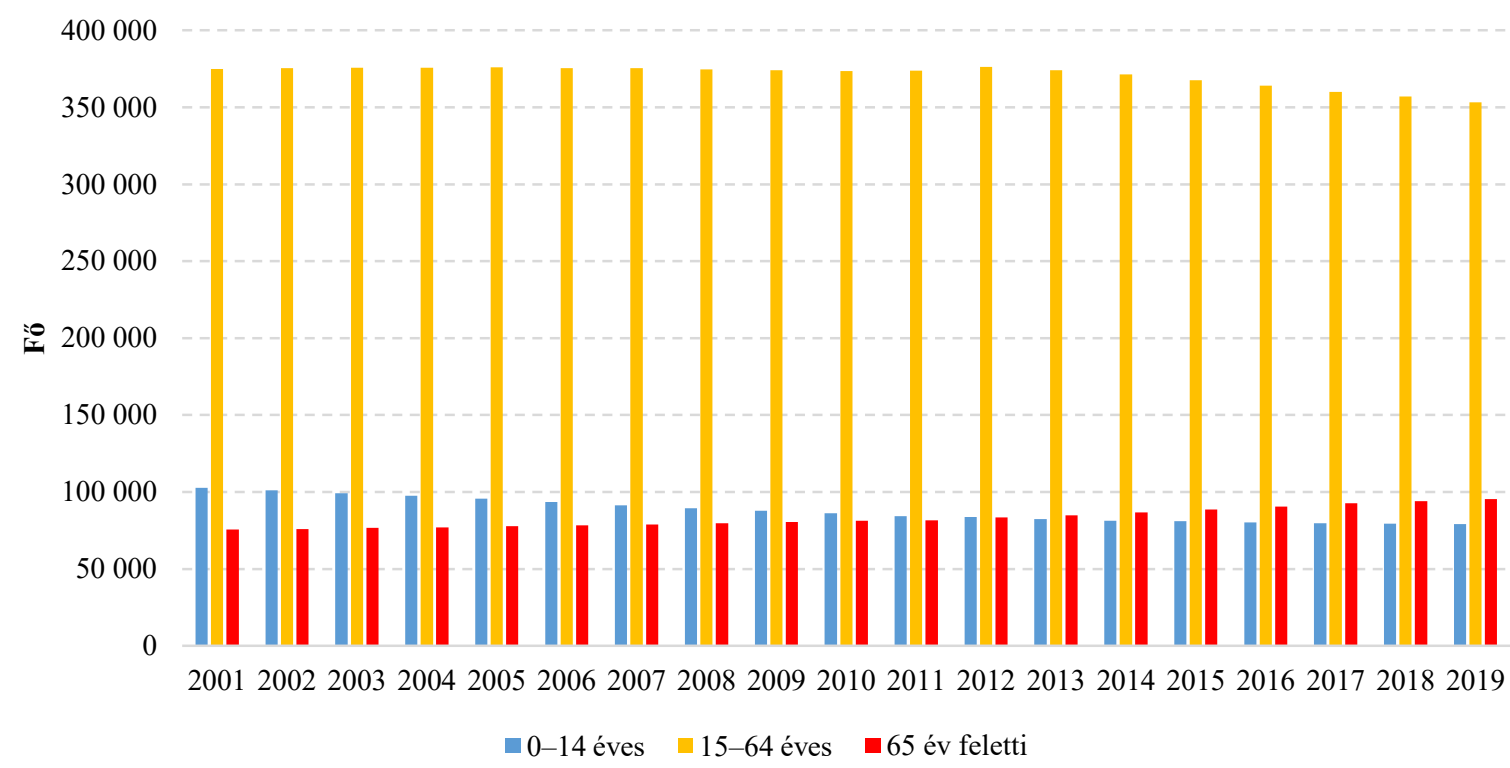

3. ábra: Hajdú-Bihar megye lakónépességének korcsoport szerinti összetétele (2001-2019)

Figure 3: Composition of the population of Hajdú-Bihar County by age group (2001-2019) Forrás: saját szerkesztés a KSH adatai alapján, 2019

A társadalmi-gazdasági folyamatok eredményeként a népesség kormegoszlását legjobban leíró öregedési ráta (az állandó népességből 100 fő 0-14 éves korú lakosra jutó 65 év felettiek száma) jelentősen megemelkedett, azaz az időskorúak száma jóval meghaladta a 0-14 éves korosztály nagyságát, de ez az 3. ábrán is jól megfigyelhetö.

A 4. ábra az öregedési ráta alakulását mutatja Magyarországon, az Észak-Alföldi régióban, Hajdú-Bihar megyében, a Debreceni járásban, és Debrecen városában. Az ábráról jól leolvasható, hogy 100 fö fiatalkorúra jutó idősek (65 év felettiek) száma az elmúlt 10 évben emelkedett minden területi dimenzióban.

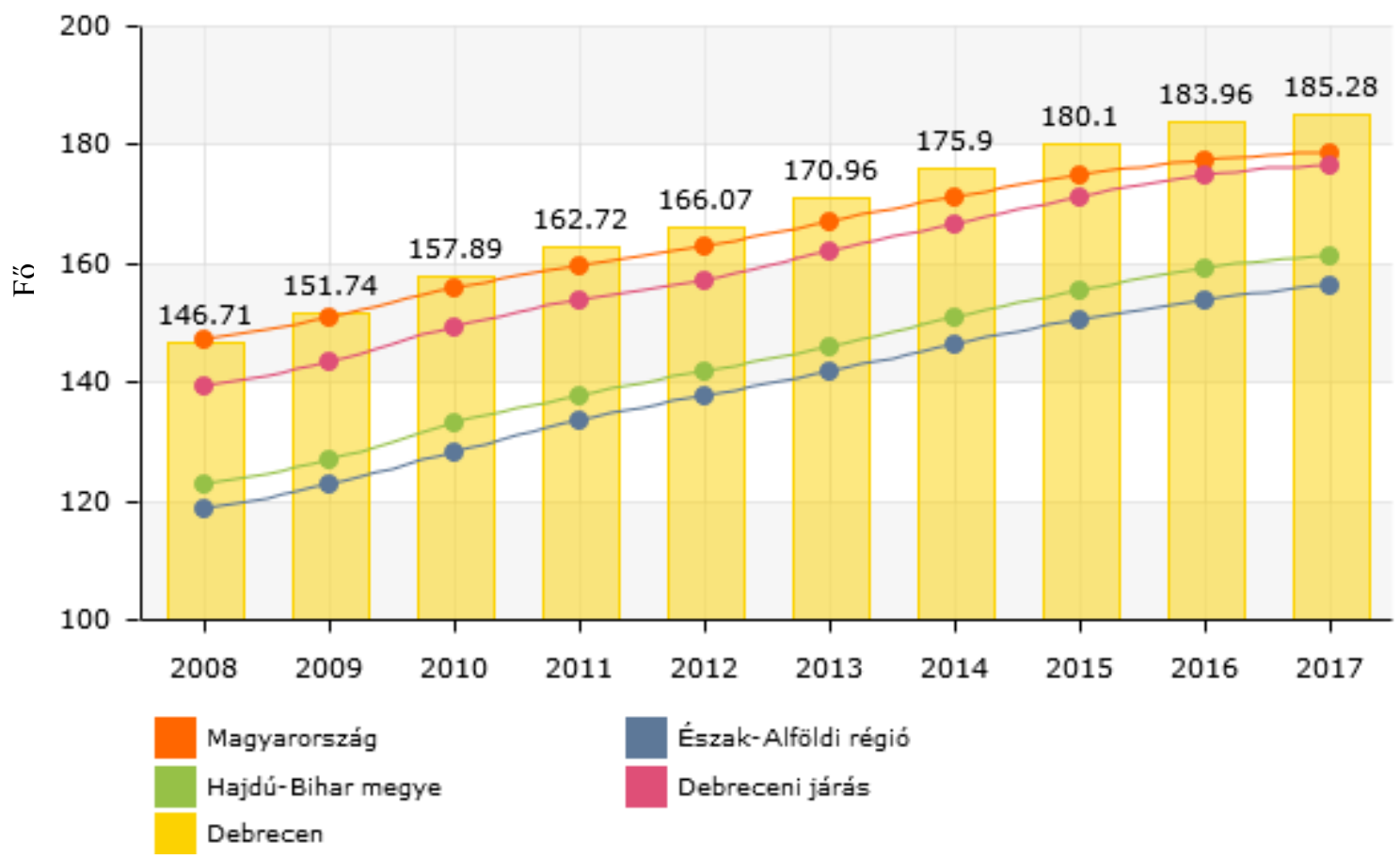

4. ábra: Az öregedési ráta alakulása egyes területeken (2008-2017)

Figure 4: Changing of ageing rate in different areas (2008-2017)

Forrás: TEIR adatai alapján, 2019 
Az adatokat jelölő vonalak szinte párhuzamosak egymással, ami azt jelenti, hogy a regionális, megyei és járási szint teljesen összhangban van az országos adatokkal. Debrecen város esetében figyelhető meg, hogy az elöregedés folyamata még inkább jellemző (itt a legmagasabb a mutató értéke, azaz 100 fö fiatalkorúra 185 fó 65 év feletti lakos jut), itt a 65 év felettiek aránya kissé magasabb a gyermekkorúak terhére (KSH, 2014). A debreceni öregedési mutató értéke 2008-ban még nem érte el az országos szintet, majd egyre jobban közelítve, 2011-től már meghaladta azt, és ez a növekvő tendencia azóta is tart. A legalacsonyabb a regionális adat, amely messze elmarad a térség adatától. Ez azt jelenti, hogy a régióban lévő települések között található olyan, ahol a fiatalok száma kedvezően befolyásolja a mutató alakulását.

A népesség nemek közötti megoszlását tekintve az elmúlt évtizedben alig történt jelentősebb változás, kismértékben csökkent a férfiak aránya, és emelkedett a nőké. A megyei értékeket tekintve elmondható, hogy a férfiak aránya néhány százalékkal alacsonyabb, mint a nőké, a lakosok $48 \%$-a férfi, és $52 \%$-a nő, amely összhangban áll az országos adatokkal (Internet 3.).

A nemek vizsgálata után az iskolai végzettség és a korosztály kapcsolatát kívánjuk elemezni. Az általános iskolától haladunk a középiskola/gimnáziumi oktatáson át egészen a felsőoktatásban résztvevőkig. Azt kívánjuk bemutatni, hogy hogyan változott az elmúlt évtizedek alatt az iskolázottság kérdése Hajdú-Bihar megye lakosai körében.

Az első iskolai végzettséggel kapcsolatos táblázatunkban (3. táblázat) azoknak az aránya látható, akik legalább az általános iskola 8. osztályát elvégezték. Az adatok az 1970-es évektől álltak igazán rendelkezésre, így ezektől az évektől kezdve be lehet mutatni, hogy az adott iskolai végzettséggel az adott korosztályba hány fö tartozik. De nemcsak ezt tudjuk megmondani, hanem azt is, hogy ez a létszám hány százalékot jelent a megfelelő korú népesség százalékában. A 3. táblázatban 1970-től egészen a 2011-es népszámlálás adataival bezárólag ezt kívántuk bemutatni.

3. táblázat: A népesség iskolai végzettség és korcsoport szerinti megoszlása Hajdú-Bihar megyében (általános iskola)

Table 3: Population by educational qualification and age group in Hajdú-Bihar County (primary school)

\begin{tabular}{|c|c|c|c|c|c|}
\hline Korcsoport, évek & $\begin{array}{c}1970 \\
(\%)\end{array}$ & $\begin{array}{c}1980 \\
(\%)\end{array}$ & $\begin{array}{c}1990 \\
(\%)\end{array}$ & $\begin{array}{c}2001 \\
(\%)\end{array}$ & $\begin{array}{c}2011 \\
(\%)\end{array}$ \\
\hline \multicolumn{6}{|c|}{ Legalább általános iskola 8. évfolyam (a megfelelő korú népesség százalékában) } \\
\hline 15-19 év & 89,2 & 93,1 & 93,9 & 93,1 & 95,8 \\
\hline $20-24$ év & 88,2 & 94,9 & 96,7 & 97,6 & 98,3 \\
\hline 25-29 év & 72,0 & 94,8 & 96,4 & 97,4 & 98,2 \\
\hline 30-34 év & 56,8 & 91,2 & 96,0 & 97,3 & 98,1 \\
\hline 35-39 év & 43,2 & 80,0 & 95,8 & 97,1 & 98,1 \\
\hline 40-44 év & 36,5 & 66,7 & 93,1 & 96,5 & 97,9 \\
\hline 45-49 év & 26,1 & 51,7 & 84,0 & 96,7 & 97,8 \\
\hline 50-54 év & 24,0 & 39,9 & 70,6 & 95,2 & 97,2 \\
\hline 55-59 év & 15,2 & 27,4 & 53,1 & 88,8 & 97,3 \\
\hline 60-64 év & 11,2 & 24,5 & 39,1 & 77,6 & 96,4 \\
\hline 65-69 év & 10,8 & 15,5 & 27,1 & 59,9 & 91,7 \\
\hline 70-74 év & 9,9 & 11,8 & 25,3 & 49,5 & 83,1 \\
\hline 75 év feletti & 8,9 & 10,7 & 15,4 & 31,7 & 58,4 \\
\hline Összesen & 45,0 & 61,7 & $\mathbf{7 4 , 7}$ & 86,3 & 93,4 \\
\hline
\end{tabular}

Forrás: saját számitás a KSH adatai alapján, 2019

A 3. táblázat adataiból egyértelműen látható, hogy az évek elörehaladtával a népességen belüli iskolázottsági szint jelentősen növekedett Hajdú-Bihar megyében, de ugyanez a tendencia zajlott le országosan is. Például a 15-19 éves korosztály esetében megfigyelhetö, hogy az 1970-es években a megyei népesség 89,2\%-a végezte el az általános iskola 8 osztályát, ami egész magas arány azt figyelembe véve, hogy a két világháború között gyakran csak 1-2-3 elemi osztályt végeztek el a fiatalok, ezzel be is fejezték tanulmányaikat, majd pedig munkába álltak. 2011-re a megyei népesség ezen korosztályának aránya viszont már közel 96\%. A legszembetünőbb talán a változás az 55-59 éves és a 
60-64 éves korosztály esetében, mivel 1970-ben még csak a megyei lakosság 11-15\%-nak „,volt meg a 8 osztálya", ez az arány a népességben belül évtizedröl évtizedre egyre nagyobb mértékben növekedett (majdnem megduplázódott évtizedenként), és 2011-re már 98\%-os értéket közelíti a Hajdú-Bihar megyei lakosok között. Az Összesen sort vizsgálva pedig látható, hogy míg a 70-es években átlagosan a lakosok 45\%-a végezte el a nyolc elemi osztályt, ez már 2011-re átlagosan több, mint a duplája, 93,4\%ra emelkedett.

A második táblázatunk, mely szintén az iskolai végzettséggel foglalkozik Hajdú-Bihar megyében az a 4. táblázat. Az előző táblázathoz hasonlóan itt is a megfelelő korú népesség százalékában kerülnek az adatok bemutatásra, de már a középfokú tanulmányok elvégezésével, befejezésével foglalkozik. Itt is megfigyelhető az a trend, hogy az 1970-es években az érettségizettek aránya a 18-19 évesek között még csak $22,5 \%$ volt, de a $20-24$ évesek között is valamivel több, mint $29 \%$ ez az arány. A többi korosztály esetében ettől csak kevesebb százalékos részesedést találunk, hiszen ha még az általános iskolát sem fejezték be, akkor gyakorlatilag lehetetlen, hogy érettségi vizsgával rendelkeztek volna. Ezt a néhány százalékot az orvosok, a tanítók, a bírók, és a magasabb tisztségviselők alkották. Korosztályonként megfigyelhetö, hogy a megyei lakónépességen belül évtizedenként növekedett az érettségivel rendelkezők aránya, de még 2001-ben is az érettségi korú fiatalok (18-24 éves kor közöttiek) 40-50\%-a rendelkezett csak érettségi bizonyítvánnyal. 2011-re már jelentősen javult a helyzet, mert ugyanebben a korosztályban már a fiatalok 45-70\%-a érettségizett. Ha az összesített adatokat vizsgáljuk, akkor az 1970-es évek szintjéhez viszonyítva Hajdú-Bihar megyében az érettségivel rendelkező lakosok aránya több, mint háromszorosára emelkedett, amelynek egyik oka az lehet, hogy a korábbi politikai berendezkedés nem szorgalmazta a diákok továbbtanulását, hanem inkább a szakmai ismeretek megszerzését részesítette előnyben, de a politikai helyzet megváltozásával előtérbe került a továbbtanulás lehetósége. A korábbi évtizedekben még nem tulajdonítottak ekkora jelentőséget az érettséginek, mert a boldoguláshoz elegendő volt a szakma ismerete (szakmunkásvizsga megléte), így a lakosok többsége (föleg az 50 év felettiek) szakmunkás vizsgával rendelkeznek. Ezt támasztják alá az adatok is, mert az 50 év felettiek között kevesebb, mint $40 \%$ az érettségizettek aránya. Egy ideje már megváltozott a közvélekedés is, hiszen ma már szinte elvárás egy érettségi bizonyítvány, és gyakran előfeltétele is egy adott munkakör betöltésének. De nem ennyire egyértelmü a magyarázat, a további okok lehetnek, hogy bizonyos csoportok nem folytatják tovább tanulmányaikat az általános iskola befejezése után, illetve időközben lemorzsolódnak a középiskolai rendszerből.

\section{4. táblázat: A népesség iskolai végzettség és korcsoport szerinti megoszlása Hajdú-Bihar megyében (középiskola/gimnázium)}

Table 4: Population by educational qualification and age group in Hajdú-Bihar County (high school)

\begin{tabular}{|l|c|c|c|c|c|}
\hline Korcsoport, évek & $\begin{array}{c}\mathbf{1 9 7 0} \\
(\%)\end{array}$ & $\begin{array}{c}\mathbf{1 9 8 0} \\
\mathbf{( \% )}\end{array}$ & $\begin{array}{c}\mathbf{1 9 9 0} \\
\mathbf{( \% )}\end{array}$ & $\begin{array}{c}\mathbf{2 0 0 1} \\
\mathbf{( \% )}\end{array}$ & $\begin{array}{c}\mathbf{2 0 1 1} \\
(\mathbf{\%})\end{array}$ \\
\hline \multicolumn{5}{|c|}{ Legalább érettségi (a megfelelö korú népesség százalékában) } \\
\hline 18-19 év & 22,5 & 29,4 & 30,2 & 38,8 & 45,7 \\
\hline 20-24 év & 29,3 & 32,3 & 39,6 & 50,4 & 70,2 \\
\hline 25-29 év & 21,3 & 31,3 & 36,7 & 40,9 & 65,6 \\
\hline 30-34 év & 17,5 & 32,3 & 32,9 & 40,6 & 56,6 \\
\hline 35-39 év & 13,8 & 25,4 & 34,1 & 39,4 & 47,9 \\
\hline 40-44 év & 12,1 & 19,8 & 34,3 & 36,1 & 45,6 \\
\hline 45-49 év & 8,8 & 15,4 & 26,4 & 35,9 & 43,5 \\
\hline 50-54 év & 8,7 & 13,5 & 20,1 & 37,0 & 39,5 \\
\hline 55-59 év & 5,2 & 9,7 & 15,6 & 30,7 & 38,1 \\
\hline 60-64 év & 3,6 & 9,1 & 13,0 & 23,5 & 39,1 \\
\hline 65-69 év & 3,9 & 5,5 & 9,5 & 17,9 & 33,7 \\
\hline $70-74$ év & 3,6 & 3,9 & 9,7 & 15,7 & 26,4 \\
\hline 75 év feletti & 3,2 & 4,0 & 5,2 & 10,9 & 18,4 \\
\hline Összesen & $\mathbf{1 3 , 1}$ & $\mathbf{1 9 , 8}$ & $\mathbf{2 5 , 7}$ & $\mathbf{3 4 , 0}$ & $\mathbf{4 4 , 9}$ \\
\hline
\end{tabular}

Forrás: saját számitás a KSH adatai alapján, 2019

Az 5. táblázat a felsőoktatásban lévők arányát mutatja be Hajdú-Bihar megyében 1970 és 2011 között. 


\section{5. táblázat: A népesség iskolai végzettség és korcsoport szerinti megoszlása Hajdú-Bihar} megyében (felsöoktatás)

Table 5: Population by educational qualification and age group in Hajdú-Bihar County (higher education)

\begin{tabular}{|l|c|c|c|c|c|}
\hline Korcsoport, évek & $\begin{array}{c}\mathbf{1 9 7 0} \\
(\%)\end{array}$ & $\begin{array}{c}\mathbf{1 9 8 0} \\
(\%)\end{array}$ & $\begin{array}{c}\mathbf{1 9 9 0} \\
(\%)\end{array}$ & $\begin{array}{c}\mathbf{2 0 0 1} \\
(\%)\end{array}$ & $\begin{array}{c}\mathbf{2 0 1 1} \\
(\%)\end{array}$ \\
\hline \multicolumn{6}{|c|}{ Egyetem, föiskola oklevél (a megfelelö korú népesség százalékában) } \\
\hline 25-29 év & 6,7 & 8,8 & 12,2 & 13,2 & 29,0 \\
\hline $30-34$ év & 4,8 & 9,3 & 11,5 & 13,8 & 25,9 \\
\hline $35-39$ év & 5,0 & 8,5 & 11,6 & 13,8 & 19,9 \\
\hline $40-44$ év & 4,0 & 6,0 & 11,9 & 12,5 & 17,3 \\
\hline $45-49$ év & 2,6 & 5,6 & 10,4 & 12,2 & 16,6 \\
\hline $50-54$ év & 3,0 & 4,6 & 7,7 & 11,9 & 14,3 \\
\hline $55-59$ év & 2,0 & 2,9 & 6,7 & 11,2 & 13,4 \\
\hline $60-64$ év & 1,6 & 2,9 & 5,6 & 7,8 & 13,0 \\
\hline $65-69$ év & 1,6 & 1,9 & 3,8 & 6,6 & 12,9 \\
\hline $70-74$ év & 1,3 & 1,5 & 4,3 & 5,6 & 9,7 \\
\hline 75 év feletti & 1,2 & 1,2 & 2,5 & 3,7 & 7,4 \\
\hline Összesen & $\mathbf{3 , 4}$ & $\mathbf{5 , 5}$ & $\mathbf{8 , 7}$ & $\mathbf{1 0 , 8}$ & $\mathbf{1 6 , 7}$ \\
\hline
\end{tabular}

Forrás: saját számítás a KSH adatai alapján, 2019

Ha az összesített adatokat vizsgáljuk meg elsőként a táblázatban, akkor jól látható, hogy az 1970-es évekhez képest 2011-re megötszöröződött a felsőfokú képesítéssel rendelkezők aránya, mert 3,4\%-ról 16,7\%-ra emelkedett a megye lakónépességén belül. az arányuk. Az nem meglepő, hogy az 1970-es és 1980-as években alacsony volt még a fiatalabb korosztály körében is a felsőfokú képesítéssel rendelkezők aránya (bőven 10\% alatti a megye lakosságából), de az 1990-es évek adatai összehasonlítva a 2001-es adatokkal sem mutatnak jelentős növekedést (maximum 2\%). Ellenben a 2001-es adatok a 2011-es adatokhoz viszonyítva, a 35 év alattiak körében már duplázódást mutatnak, megnőtt a „népszerüsége” a diplomának. Ez a folyamat azóta is tart, és talán mondhatjuk azt is, hogy még nagyobb teret nyert, hiszen a felsőoktatásba beiskolázottak száma évről évre növekszik. Érdekességként említhető az is, hogy a legnagyobb növekedés a 60 év felettiek esetében tapasztalható, hiszen 1970-ben még 60-69 éves korúak 1,6\%-a rendelkezett felsőfokú végzettséggel, ez az arány 2011-ben már 13\% volt, ami nyolcszoros növekedést jelent. Ennek egyik oka az lehet, hogy a felsőoktatásban megszerezhető tudás felértékelődött, és megnövekedett az igény a diploma iránt mind a munkáltatók, mind a hallgatók, azaz a jövőbeli munkavállalók részéről.

Hajdú-Bihar megye esetében, ha megvizsgáljuk a 2000 és 2018 közötti időszak munkanélküliségi rátáját (5. ábra), akkor jól látható, hogy a megye munkanélküliségi rátája a vizsgált időszak minden évében meghaladta az országos átlagot. Egyetlen kivétel van, a 2004-es év, amikor néhány százalékkal alacsonyabb volt a megye munkanélküliségi rátája az országos átlagnál. Ezt követően (2005 után) viszont megfigyelhető az 5. ábra adatai alapján, hogy a megyei ráta 1-1,5\%-al, de esetenként 4,5-5\%-al is magasabb, mint az országos átlag (2014 és 2015-ös évben), ami az itt élők számára kedvezőtlen.

Az ábrára rápillantva azt is megállapíthatjuk, hogy a megyei munkanélküliségi adatok letükrözik az országos adatot, követik annak minden hullámzását. Ha csak a megyei munkanélküliségi rátát vizsgáljuk, azt kell mondanunk, hogy a vizsgált időszakban soha nem volt ilyen alacsony (5,6\%), mint 2018-ban, és az országos átlaghoz képest is kevesebb, mint 2\% az eltérés. Egyedül a 2004-es adat (5,7\%) közelíti meg ez az értéket. Ez azt jelenti, hogy az elmúlt években az országos csökkenéssel párhuzamosan a megyei munkaerő-piaci folyamatok még inkább lehetővé tették a munkanélküliségi ráta csökkenését, és ehhez hozzájárultak a multinacionális cégek munkahely-teremtési tevékenységei is. 
5. ábra: A munkanélküliség ráta alakulás az Észak-alföldi régió megyéiben összehasonlitva az országos átlaggal (2000-2018)

Figure 5: Unemployment rate in the counties of the Northern Great Plain region compared to the national average (2000-2018)

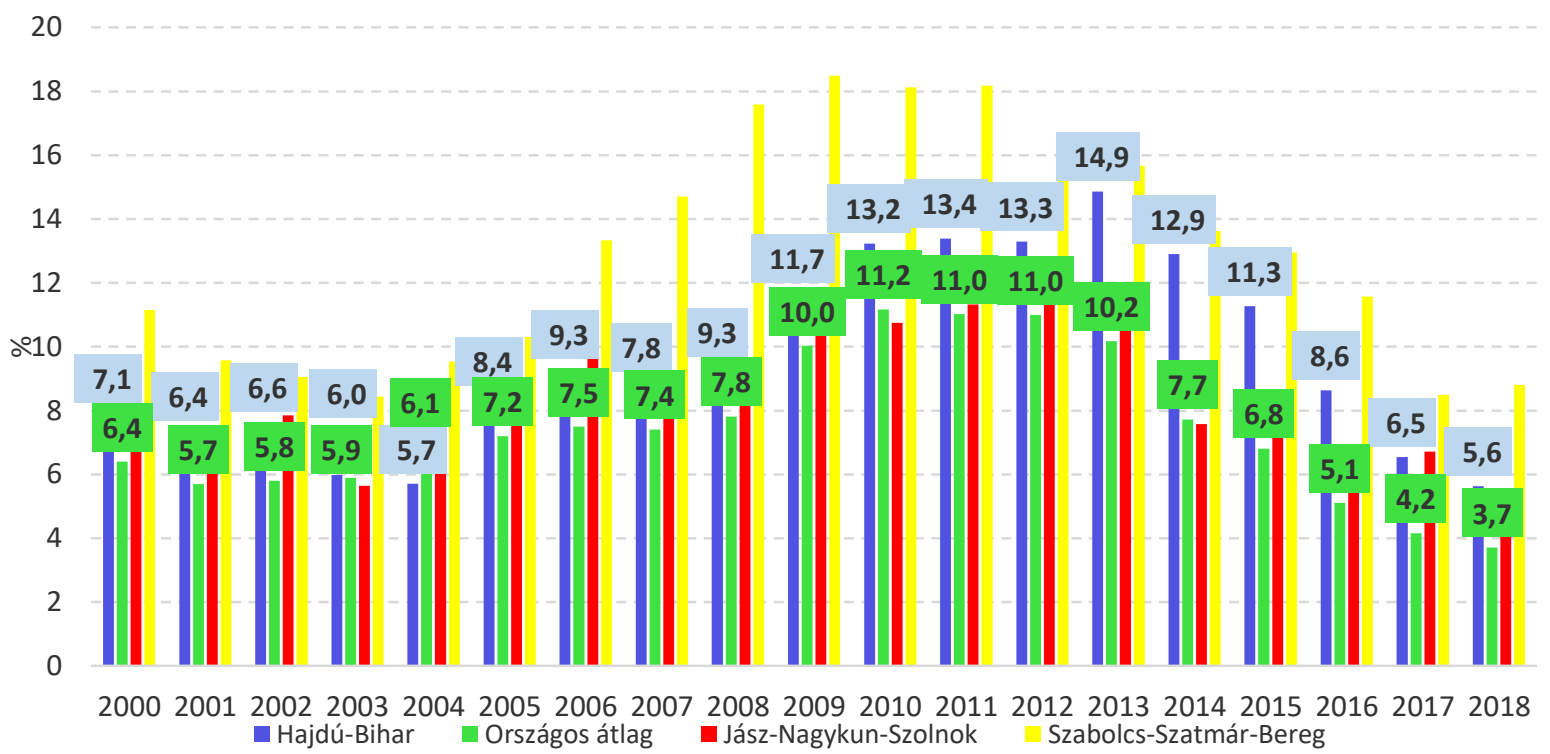

Forrás: saját szerkesztés a KSH adatai alapján, 2019

Az Észak-alföldi régió másik két megyéjével összehasonlítva megállapítható, hogy Jász-NagykunSzolnok megye adatai több évben is kismértékben, de alacsonyabbak a Hajdú-Bihar megyei adatoknál, míg Szabolcs-Szatmár-Bereg munkanélküliségi rátája minden esetben magasabbak. A KSH legfrissebb területi adatai szerint a munkanélküliek aránya a gazdaságilag aktív népességen belül 10 megyében és a fövárosban mérséklődött, 9 megyében pedig emelkedett. A növekedés Heves és Békés megyékben következett be. A többi megyével összehasonlítva azt mondhatjuk, hogy a legfrissebb KSH, 2019 területi adatok szerint az elmúlt évben a munkanélküliségi ráta országosan 3,3\% volt, a legalacsonyabb Györ-Moson-Sopron megyében $(0,8 \%)$, és a legmagasabb Szabolcs-Szatmár-Bereg megyében volt $(8,4 \%)$, a Hajdú-Bihar megyei munkanélküliségi ráta 5,1\% volt, ami a negyedik legmagasabb érték.

A 6. ábrán a teljes munkaidőben alkalmazásban állók havi nettó átlagkeresete látható 2000 és 2018 között ábrázolva Hajdú-Bihar megyében, összehasonlításképpen ábrázolásra került Budapest, és az országos átlag is. Az ábra alapján megállapíthatjuk, hogy Hajdú-Bihar megye adatai Budapesttel összehasonlítva, az évek elörehaladtával egyre nagyobb a különbséget mutat, a nettó átlagkereset tekintetében. A vizsgált időszak utolsó évében több, mint 105 ezer forintos különbség van a Hajdú-Bihar megyei és a budapesti átlagkereset között, ami igen jelentős. Többek között ez is egy magyarázata annak, hogy miért vándorolnak el a megyéből leginkább Budapestre illetve Pest megyébe. Az országos átlag 2018-ban 239 ezer forint volt, a megyei átlagkereset még ettől is jelentősen elmarad. Ha a vizsgált időszak utolsó 10 évét nézzük, akkor Budapesten és országosan is megfigyelhetö, hogy a bérek megduplázódtak (145 ezer forintról 299 ezer forintra illetve 119 ezer forintról 239 ezer forintra emelkedtek), és Hajdú-Biharban is 1,8-szeresére növekedtek (106 ezer forintról 194 ezer forintra). Összességében azt a következtetést vonhatjuk le, hogy hosszú távon a megyében élők nettó átlagkeresetének változása kismértékben elmarad az országos és a budapesti keresetek emelkedésétől, ezt a tendenciát folytatva kevés az esély arra, hogy jelentős változás legyen a térségben élők bérének emelkedésére. 


\section{0}

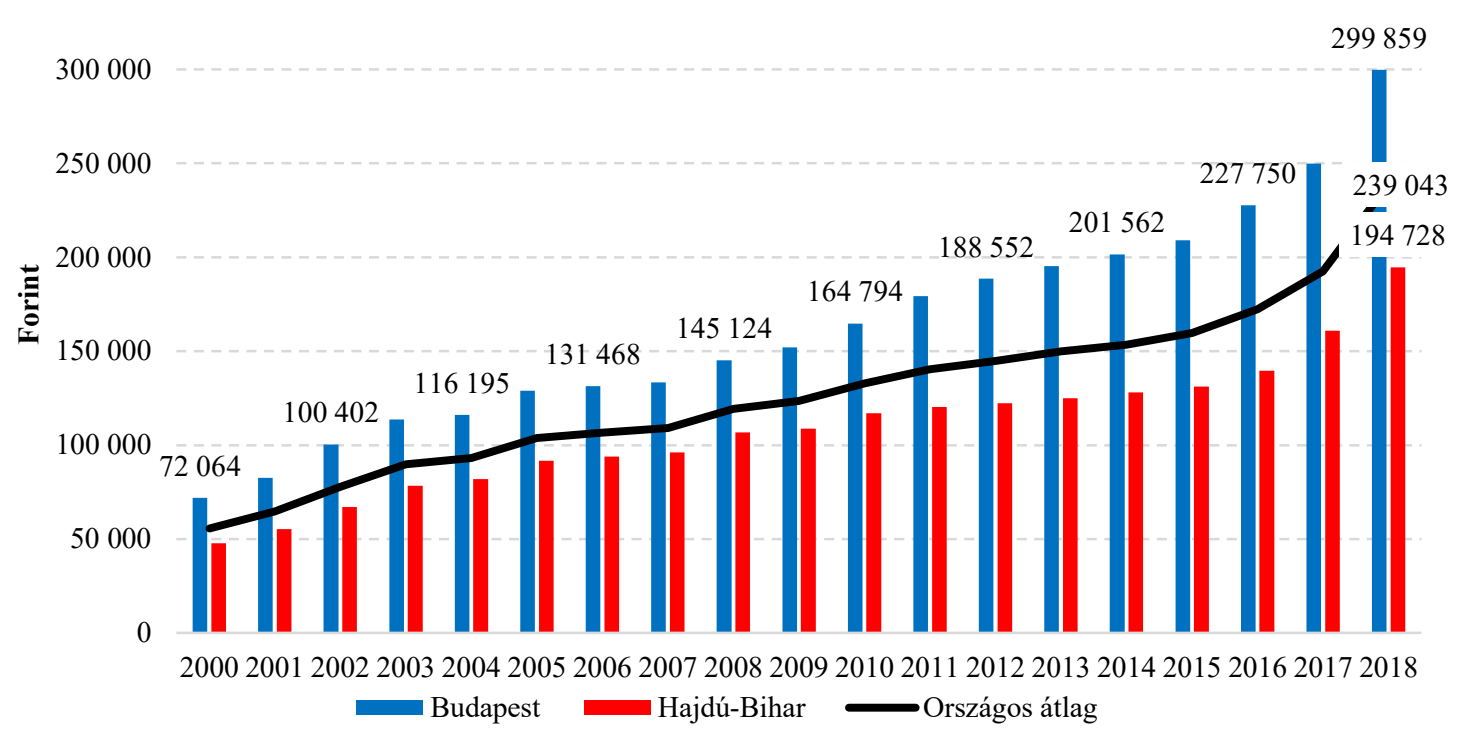

6. ábra: A teljes munkaidőben alkalmazásban állók havi nettó átlagkeresete (2000-2018)

Figure 6: Average monthly net earnings of full-time employees (2000-2018)

Forrás: saját szerkesztés a KSH adatai alapján, 2019

A havi nettó átlagkeresetet Hajdú-Bihar megyében gazdasági áganként vizsgálva megállapítható, hogy a „Villamos energia-, gáz-, gőzellátás, légkondicionálás” szektorban a legmagasabbak a bérek, átlagosan 330 ezer forint, amely 278 ezer forint a fizikai dolgozók esetében, és 374 ezer forint a szellemi dolgozók esetében, ami nem olyan nagymértékü különbség. A második legmagasabb az átlagkereset a „Pénzügyi, biztosítási tevékenység”-et végzők körében, átlagosan 299 ezer forint, de itt már jelentős különbség mutatkozik a fizikai (130 ezer forint) és a szellemi (308 ezer forint) dolgozók bére között. A harmadik legjövedelmezőbb gazdasági ág az „Információ és kommunikáció”, átlagosan 243 ezer forintos nettó havi jövedelemmel, ahol a fizikai foglalkozásúak 162 ezer forintot, míg a szellemi foglalkozásúak 250 forintot keresnek havonta. A megyében a legnagyobb létszámmal rendelkező ágazatok a „Feldolgozóipar”, ahol több, mint 25 ezren dolgoznak (ebböl 18 ezer fö fizikai dolgozó) és az „Oktatás”, ahol 21 ezer fö dolgozik (ebböl 18 ezer fö szellemi foglalkoztatott) (NAV és MÁK, 2019) ${ }^{1}$.

\section{Következtetések, javaslatok}

A tanulmány célja az volt, hogy áttekintést nyújtson Hajdú-Bihar megye társadalmi helyzetének alakulásáról. A kutatásunk során megvizsgált adatokból azt a következtetést vonhatjuk le, hogy HajdúBihar megye a második legnagyobb lélekszámú megye az Észak-Alföldi régióban, az elmúlt harminc évben a lakosok száma kis mértékben változott, 2001 óta (ekkor volt a legnagyobb létszám a megyében 553 ezer fővel) folyamatos csökkenés tapasztalható, hasonló tendenciát mutat a népsürüség is. A megye lakónépességében a tényleges szaporodást befolyásoló tényezők vizsgálata alapján azt mondhatjuk, hogy a természetes népesedési folyamatokat tekintve természetes fogyás tapasztalható, a többi megyével összehasonlításban a hetedik helyet foglaljuk el a népesség csökkenést tekintve.

Az elöregedési ráta vizsgálatából azt a megállapítást tehetjük, hogy értéke az elmúlt 10 évben emelkedett minden területi dimenzióban (országos, regionális, megyei, járási, megyeszékhely szintjén), különösen igaz ez Debrecen városára, ahol 100 fő fiatalkorúra (0-14 éves korosztály) 185 fö 65 év feletti lakos jut, ez magasabb az országos átlagnál is.

A nemek arányát tekintve a Hajdú-Bihar megyei lakosok között arra a következtetésre jutottunk, hogy kismértékben, de nagyobb arányt képviselnek a nők (52\%) az arányuk a populációból, mely összhangban van az országos adatokkal.

\footnotetext{
${ }^{1}$ Az adatok a Nemzeti Adó-és Vámhivataltól átvett ún. járulékbevallásokból, valamint a Magyar Államkincstár adminisztratív nyilvántartásából átvett adatokból származnak. A havi kereset és létszámstatisztika során használt vonatkozási kör meghatározása a szervezetek adott havi tényleges létszáma alapján történik.
} 
Az iskolai végzettség és az életkor összefüggéseit általános iskolára, középiskolára, és felsőoktatásra külön-külön elemeztük. Összességében arra jutottunk, hogy az évek elörehaladtával a népességen belüli iskolázottsági szint jelentősen növekedett Hajdú-Bihar megyében. Míg az 1970-es években átlagosan a lakosok 45\%-a végezte el az általános iskolát, ez már 2011-re átlagosan több, mint a duplája, 93,4\%-ra emelkedett. A megyei lakónépességen belül évtizedenként növekedett az érettségivel rendelkezők aránya is, 2011-re már a fiatalok 45-70\%-a érettségizett. Ha az összesített adatokat vizsgáljuk, akkor az 1970-es évek szintjéhez viszonyítva Hajdú-Bihar megyében az érettségivel rendelkező lakosok aránya több, mint háromszorosára emelkedett. A felsőoktatásban is hasonló tendencia zajlott le, de még nagyobb mértékben, hiszen az 1970-es évekhez képest 2011-re megötszöröződött a felsőfokú képesítéssel rendelkezők aránya.

A munkanélküliségi ráta vizsgálatakor arra jutottunk, hogy a Hajdú-Bihar megyei érték a 2000-es évtől kezdve (egyetlen kivétellel) minden évben meghaladta az országos átlagot, a többi megyével összehasonlítva pedig azt mondhatjuk, hogy még mindig jelentős a lemaradásunk, mert a legfrissebb adatok szerint is a negyedik legmagasabb munkanélküliségi rátával rendelkezünk.

A nettó átlagkereset volt a vizsgálatunk utolsó mutatója, melynek Hajdú-Bihar megyei értékei a budapestivel összehasonlítva - az évek elörehaladtával - egyre nagyobb a különbséget mutat (jelenleg több, mint 105 ezer forint az eltérés).

\section{Összefoglalás}

Jelen tanulmányban igyekeztünk a legfontosabb társadalmi mutatókat kiválasztani, és elemezni, magyarázni, összehasonlítani országos, budapesti, vagy más megyékkel. A társadalmi mutatók elemzésekor elöször a népesség számát vizsgáltuk meg 1870-es évektől napjainkig. Az elemzést HajdúBihar megye népmozgalmi eseményeivel folytattuk, ahol bemutattuk, hogy a természetes szaporodás illetve fogyás, és a belföldi és nemzetközi migrációs folyamatok hogyan alakítják a megye lakóinak számát. A későbbiekben részleteztük, hogyan alakul a természetes fogyás illetve szaporodás (az élve születések és a halálozások különbözete ezer lakosra vetítve) magyarországi, Észak-Alföldi régiós, Hajdú-Bihar megyei, Debreceni járási és Debrecen város esetében, és bemutatásra kerültek a belföldi migráció célpontjai is. Majd a megye lakónépességének nemek és korcsoport szerinti összetételét, majd az öregedési ráta alakulását mutattuk be magyarországi, Észak-Alföldi régiós, Hajdú-Bihar megyei, Debreceni járási és Debrecen város viszonylatában. Ezt követően megvizsgáltuk a népesség iskolai végzettség és korcsoport szerinti megoszlását az általános iskolai, középfokú- és a felsőoktatásban, Hajdú-Bihar megyében a népszámlálási adatok alapján. A kutatás céljai között szerepeltek a foglalkoztatási adatok bemutatása is, így elemeztük a munkanélküliségi rátát a megyében - országos adatokkal és a szomszédos megyékkel összehasonlítva. Végezetül a teljes munkaidőben alkalmazásban állók havi nettó átlagkeresetét vettük górcső alá, és megvizsgáltuk hosszú távú alakulását országos, megyei összehasonlításban is.

\section{Irodalomjegyzék}

Bartha E. (1992): Vallásökológia. Szakrális ökoszisztémák szerveződése és müködése a népi vallásosságban. Ethnica, Debrecen-Bp. 202 p.

Bajkó M. - Barcza J.né - Bölcskei G. - Csohány J. - Czeglédy S. - Dankó I. - Fekete Cs.- Gaál B. - Győri L. J.- Kocsis E. - Kormos L. - Makkai L. - G. Szabó B. - Szabó L. A. - Takács B. - Tóth B. (1988): A Debreceni Református Kollégium Története. (szerkesztette Barcza J.). Kiadó: A Magyarországi Református Egyház Zsinati Irodájának Sajtóosztálya. Budapest, 1988. pp 10-11.

Internet 1.: Euro- Régió Ház Közhasznú Nonprofit Kft. és INNOVA Észak-Alföld Regionális Fejlesztési és Innovációs Ügynökség Nonprofit Kft. (2014): „Debrecen Megyei Jogú Város Településfejlesztési Koncepciója És Integrált Településfejlesztési Stratégiája 2014-2020”. https://www.debrecen.hu/assets/media/file/hu/4821/debrecenmjv-its-megalapozo-vizsgalatmelleklettel.pdf

Internet 2.: https://www.debrecen.hu

Internet 3.: https://nyilvantarto.hu/hu/statisztikak?stat=kozerdeku 
Régiókutatás Szemle 2020. V. évf. 1. sz.

DOI: $10.30716 / \mathrm{RSZ} / 20 / 1 / 3$

Központi Statisztikai Hivatal (KSH) (2014): Magyarország településhálózata 1. Agglomerációk, település együttesek. ISBN 978-963-235-460-6. ISSN 2064-8073. http://www.ksh.hu/docs/hun/xftp/idoszaki/mo telepuleshalozata/agglomeracio.pdf

Központi Statisztikai Hivatal (KSH) (2017): A belföldi vándorlás aktuális trendjei, 2012-2017. https://www.ksh.hu/docs/hun/xftp/stattukor/belfvand17.pdf

Központi Statisztikai Hivatal (KSH) (2018): https://www.ksh.hu/thm/2/indi2 3 _2.html Központi Statisztikai Hivatal (KSH) (2019): Fókuszban a megyék. Térségi összehasonítás. http://www.ksh.hu/teruleti-adatok; http://www.ksh.hu/nepszamlalas/

Magyar Államkincstár (MÁK) (2019): Adminisztratív nyilvántartásából átvett adatok. Nemzeti Adó- és Vámhivatal (NAV) (2019): A járulékbevallásokból származó adatok. Országos Területfejlesztési és Területrendezési Információs rendszer (TEIR) (2019): Helyzet-Tér-Kép. https://www.teir.hu/helyzet-ter-kep/ 